\title{
Improvement of Learning Outcomes How to Maintain Blood Circulation Organ Through The Cooperative Learning Method of Class $5^{\text {th }}$ Students
}

\author{
Lis Setyawati \\ Universitas Sebelas maret \\ lissetyawati0724@gmail.com
}

\section{Article History}

accepted $14 / 11 / 2020$

approved $21 / 11 / 2020$

published 26/11/2020

\begin{abstract}
The purpose of this study was to determine the improvement of learning outcomes in Theme 4 Sub-theme 3 Ways to Maintain Circulatory Organs with the Cooperative Learning method for 5th grade students of SD Negeri Soneyan 03 Margoyoso Pati for the 2020/2021 academic year. The form of this research is Classroom Action Research which is carried out in three cycles. The learning improvement that is carried out is an action to improve the pre-cycle learning outcomes that have not achieved the learning objectives as expected by the researcher. In cycle 1 , the result is that only $55.56 \%$ and $44.44 \%$ complete students are still incomplete. In cycle 2 , the result is $83.33 \%$ of students have reached the completeness and $16.67 \%$ have not been completed. In cycle 3, the result was that the completeness percentage reached $88.89 \%$ and the incomplete percentage was only $11.11 \%$. From the research results indicate an increase in student learning outcomes on theme 4 sub-themes 3 . This proves that the Cooperative Learning method is able to improve student learning outcomes.
\end{abstract}

Keywords: learning outcomes, cooperative learning

\begin{abstract}
Abstrak
Tujuan penelitian ini adalah untuk mengetahui peningkatkan hasil belajar Tema 4 Subtema 3 Cara Memelihra Organ Peredaran Darah dengan metode Cooperative Learning pada siswa kelas 5 SD Negeri Soneyan 03 Margoyoso Pati Tahun Pelajaran 2020/2021. Bentuk penelitian ini adalah Penelitian Tindakan Kelas yang dilaksanakan dalam tiga siklus. Perbaikan pembelajaran yang dilakukan merupakan tindakan perbaikan hasil pembelajaran pra siklus yang belum mencapai tujuan pembelajaran sesuai yang diharapkan peneliti. Pada siklus 1 hasilnya siswa yang mencapai ketuntasan hanya 55,56\% dan 44,44\% masih belum tuntas. Pada siklus 2 hasilnya 83,33\% siwa sudah mencapai ketuntasan dan 16,67\% belum tuntas. Pada siklus 3 hasilnya presentase ketuntasan mencapai 88,89\% dan presentase tidak tuntas hanya $11,11 \%$. Dari hasil penelitian menunjukkan adanya peningkatan hasil belajar siswa pada tema 4 subtema 3. Hal ini membuktikan bahwa metode Cooperative Learning mampu meningkatkan hasil belajar siswa.
\end{abstract}

Kata kunci: hasil belajar, cooperative learning

Social, Humanities, and Education Studies (SHEs): Conference Series https://jurnal.uns.ac.id/shes

p-ISSN 2620-9284

e-ISSN 2620-9292 


\section{PENDAHULUAN}

Undang - Undang RI No. 20 Tahun 2003 tentang Sistem Pendidikan Nasional pasal 1 menjelaskan pendidikan adalah usaha sadar dan terencana untuk mewujudkan suasana belajar dan proses pembelajaran agar peserta didik secara aktif mengembangkan potensi dirinya untuk memiliki kekuatan spiritual keagamaan, pengendalian diri, kepribadian, kecerdasan, akhlak mulia, serta keterampilan yang diperlukan dirinya, masyarakat, bangsa dan negara.

Pada masa pandemi seperti sekarang ini, tujuan pendidikan haruslah tetap harus tercapai, pembelajaran yang kondusif juga harus tetap dilaksanakan demi mencapai tujuan pendidikan tersebut. Tetapi pada kenyataannya pembelajaran yang dilaksanakan secara daring pada masa sekarang ini menimbulkan berbagai permasalahan dalam proses pembelajaran. Mulai dari keterbatasan sarana dan prasarana yang ada sampai dengan keterbatasan ekonomi warga masyarakat menjadi permasalahan yang kompleks.

Data awal menunjukkan hasil belajar siswa kelas V SDN Soneyan 03 belum maksimal. Faktor penyebabnya adalah siswa masih kurang aktif dan kurang termotivasi dalam proses pembelajaran,siswa masih belum terbiasa dengan sistem pembelajaran daring dari rumah karena terbiasa berinteraksi langsung dengan teman temannya, guru belum menggunakan media yang mampu meningkatkan keaktifan siswa, penyampaian materi masih banyak menggunakan metode ceramah, selain itu siswa belum memiliki semangat belajar yang tinggi yang mampu meningkatkan hasil belajar siswa, jumlah siswa yang dapat mencapai Kriteria Ketuntasan Minimum (KKM) belum mencapai $70 \%$ dari besarnya nilai KKM di SD Negeri Soneyan 03 yaitu sebesar 70.

Salah satu metode pembelajaran inovatif yang dapat mengatasi masalah tersebut adalah dengan menerapkan metode Cooperative Learning. Menurut Padiya (2008) pembelajaran kooperatif merupakan suatu pembelajaran yang mengutamakan adanya kerjasama, yakni kerjasama antar siswa dalam kelompok untuk mencapai tujuan pembelajaran. Para siswa dibagi menjadi kelompok-kelompok kecil dan diarahkan untuk mempelajari materi pelajaran yang telah ditentukan. Proses pembelajaran dengan model pembelajaran kooperatif dimulai dengan membagi siswa menjadi kelompok-kelompok kecil ( 3 - 5 siswa per kelompok).

Rumusan masalah dalam penelitian ini adalah 1) apakah metode pembelajaran Cooperative Learning dapat meningkatkan hasil belajar Tema 4 Sub Tema 3 Cara Memelihra Organ Peredaran Darah pada siswa kelas 5 SD Negeri Soneyan 03 Margoyoso Pati Tahun Pelajaran 2020/2021? 2) bagaimana metode pembelajaran Cooperative Learning dapat meningkatkan hasil belajar Tema 4 Sub Tema 3 Cara Memelihara Organ Peredaran Darah pada siswa kelas 5 SD Negeri Soneyan 03 Margoyoso Pati Tahun Pelajaran 2020/2021?

Berdasarkan rumusan masalah yang telah diuraikan, maka tujuan dari penilitian ini adalah 1) untuk mengetahui peningkatkan hasil belajar Tema 4 Sub Tema 3 Cara Memelihra Organ Peredaran Darah dengan metode Cooperative Learning pada siswa kelas 5 SD Negeri Soneyan 03 Margoyoso Pati Tahun Pelajaran 2020/2021. 2) untuk mengetahui apakah terdapat peningkatkan hasil belajar Tema 4 Sub Tema 3 Cara Memelihara Organ Peredaran Darah dengan metode Cooperative Learning pada siswa kelas 5 SD Negeri Soneyan 03 Margoyoso Pati Tahun Pelajaran 2020/2021.

\section{METODE}

Jenis penelitian yang digunakan adalah penelitian tindakan kelas. Subjek penelitian ini adalah Siswa kelas 5 SD Negeri Soneyan 03 yang terdiri dari 9 siswa lakilaki berjumlah dan 9 siswa perempuan. Waktu pelaksanaan penelitian ini adalah semester 1 tahun ajaran 2020/2021 bulan November 2020. Peneliti terlebih dahulu melakukan identifikasi masalah dengan mengambil hasil analisis nilai tes ulangan 
harian yang diperoleh dari pembelajaran dalam Tema 4 Sub Tema 3 Cara Memelihara Organ Peredaran Darah Manusia materi pantun, gotong royong dan interaksi sosial, selanjutnya peneliti menganalisis data awal. Teknik analisis data hasil belajar siswa menggunakan penghitungan presentase keberhasilan atau ketercapaian siswa dalam menguasai materi. Dalam penelitian ini peneliti dikatakan berhasil jika $75 \%$ siswa sudah mendapatkan nilai baik. Jika dalam penelitian ini siklus 1 belum berhasil dilanjutkan ke siklus selanjutnya yaitu siklus 2, dan jika masih belum berhasil maka dilanjutkan ke siklus ke 3 . Jika sudah sampai siklus 3 penelitian ini belum berhasil maka peneliti akan menghentikan penelitian yang dilakukan.

\section{HASIL DAN PEMBAHASAN}

Penelitian tindakan kelas ini dilaksanakan di kelas V SDN Soneyan 03. Penelitian tindakan kelas ini dilaksanakan dalam 3 siklus untuk menentukan apakah metode pembelajaran Cooperative Learning dapat meningkatkan hasil belajar Tema 4 Sub Tema 3 Cara Memelihara Organ Peredaran Darah pada siswa kelas 5 SD Negeri Soneyan 03 Margoyoso Pati Tahun Pelajaran 2020/2021.

Kegiatan pada siklus ke-1 hasil tes dipakai untuk menggambarkan kondisi dan hasil belajar yang dicapai siswa setelah diadakan perbaikan pembelajaran dalam Tema 4 Sub Tema 3 Cara Memelihara Organ Peredaran Darah Manusia materi Pantun, Gotong Royong dan Interaksi Sosial dengan menggunakan model pembelajaran Cooperative Learning yang sudah menunjukkan peningkatan, namun belum sesuai harapan dan tujuan. Sedangkan siklus 2 merupakan tes lanjutan dari siklus 1 dan masih menggunakan metode yang sama. Kegiatan siklus 2 merupakan pengembangan materi dari siklus 1 . Selanjutnya pada siklus 3 perbaikan dari siklus 2 dengan metode yang sama.

Berdasarkan hasil analisis nilai tes ulangan harian yang diperoleh dari pembelajaran dalam Tema 4 Sub Tema 3 Cara Memelihara Organ Peredaran Darah Manusia menunjukkan bahwa hanya $38,89 \%$ atau sebanyak 8 siswa yang dapat mencapai ketuntasan dalam belajar di kelas V SDN Soneyan 03.

Tabel 1. Hasil Analisis Nilai Tes

\begin{tabular}{cccccc}
\hline No & $\begin{array}{c}\text { Jumlah } \\
\text { siswa }\end{array}$ & Nilai & $\begin{array}{c}\text { Bobot } \\
\text { Skor }\end{array}$ & Prosentase & Tuntas/Belum \\
\hline 1 & 7 & 70 & 560 & 38,89 & Tuntas \\
2 & 3 & 60 & 180 & 16,67 & Belum \\
3 & 2 & 50 & 100 & 11,11 & Belum \\
4 & 3 & 40 & 120 & 16,67 & Belum \\
5 & 2 & 30 & 60 & 11,11 & Belum \\
6 & 1 & 20 & 20 & 5,55 & Belum \\
Jumlah & 18 & & 1040 & 100 & \\
\hline
\end{tabular}


Tabel 4.1. Persebaran Frekuensi Hasil Belajar Tema 4 Sub Tema 3 Cara Memelihara Organ Peredaran Darah Manusia pada Kondisi Awal

Pada kegiatan siklus 1 ini peneliti menggunakan metode pembelajaran Cooperative Learning. Berikut adalah data hasil perbaikan pembelajaran siklus 1 melalui tes formatif.

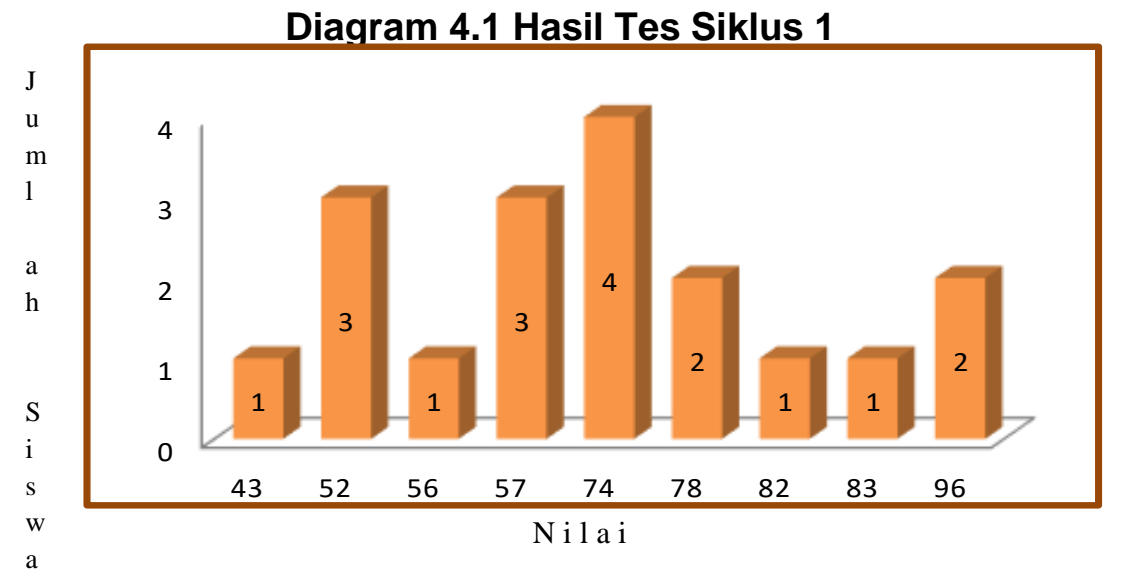

Dari diagram di atas terlihat bahwa hasil tes formatif pembelajaran Tema 4 Sub Tema 3 Cara Memelihara Organ Peredaran Darah Manusia materi pantun, gotong royong dan interaksi sosial pada siswa kelas V SDN Soneyan 03 yang terdiri dari 18 siswa terdapat peningkatan hasil belajar. Dari 18 peserta didik, ada 10 siswa yang tuntas dan 8 siswa belum tuntas / belum mencapai ketuntasan minimal belajar. Siswa yang mencapai ketuntasan hanya $55,56 \%$ dan $44,44 \%$ masih belum tuntas, sehingga penulis masih perlu melaksanakan pembelajaran pada siklus ke-2.

\section{Diagram 4.2 Hasil Tes Siklus 2}

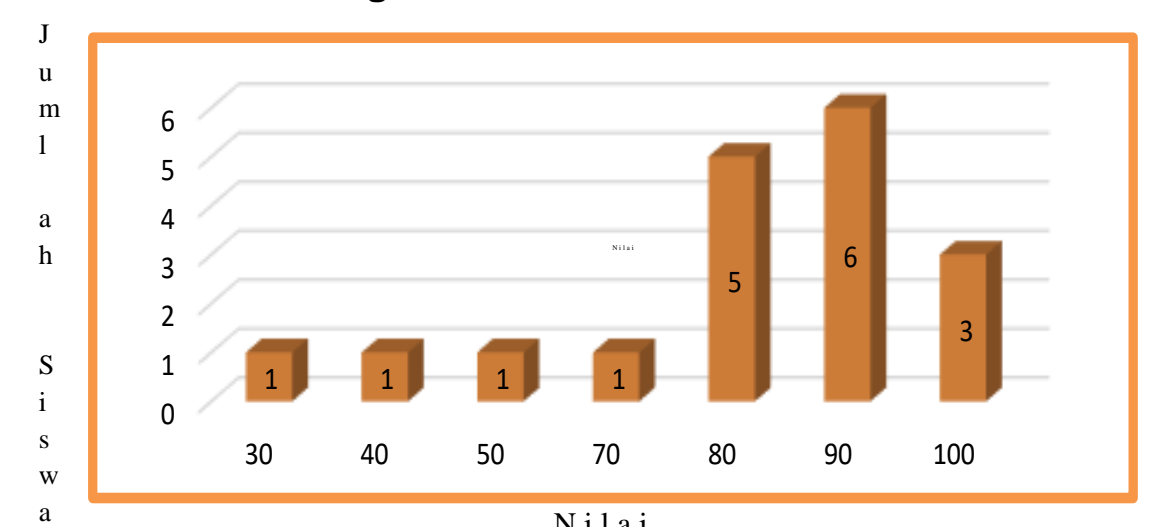

Dari hasil diagram batang diatas terlihat jelas bahwa terjadi peningkatan nilai tes siswa yang signifikan. Dari 18 siswa terdapat 15 siswa yang sudah mencapai ketuntasan belajar sedangkan 3 siswa belum mencapai ketuntasan. Pada perbaikan siklus 2 ini 83,33\% siwa sudah mencapai ketuntasan. Untuk menyempurnakan penelitian, maka dilanjutkan dengan siklus 3 yang hasilnya dapat dipaparkan pada diagram berikut: 
Diagram 4.3 Hasil Tes Siklus 3

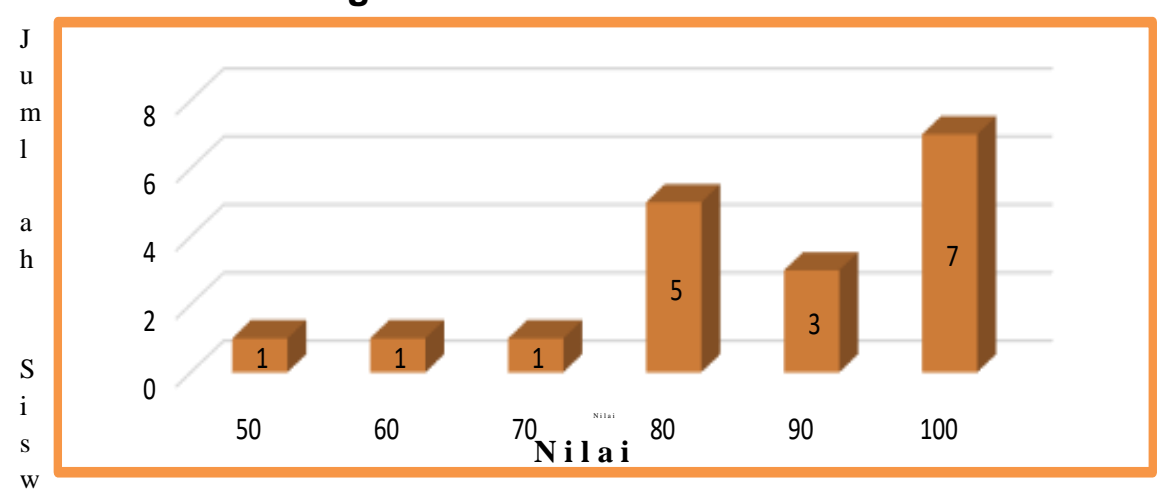

Berdasarkan penjabaran siklus 1, siklus 2, dan siklus 3 di atas. Hasilnya menunjukkan adanya peningkatan hasil belajar siswa. Untuk lebih jelasnya dapat dilihat pada diagram dibawah ini.

Diagram 4.4

Peningkatan Hasil Belajar Siswa pada Pra Siklus, Siklus 1, Siklus 2, dan Siklus 3

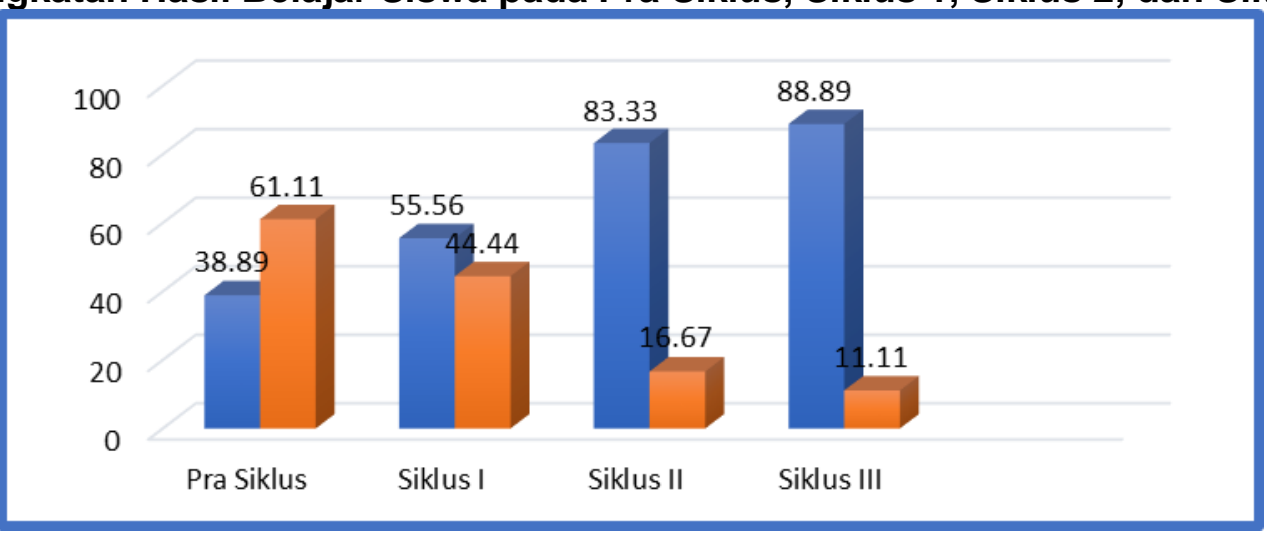

Berdasarkan diagram di atas menunjukkan bahwa adanya peningkatan hasil belajar Tema 4 Sub Tema 3 Cara Memelihara Organ Peredaran Darah Manusia materi Pantun, Gotong Royong dan Interaksi Sosial dari mulai pra siklus (sebelum ada tindakan) sampai dengan diadakan tindakan siklus 1, siklus 2, dan siklus 3. Dari pra siklus sebanyak 38,89\% siswa yang tuntas, kemudian pada siklus 1 terjadi peningkatan sebanyak 55,56\% siswa yang tuntas, kemudian pada siklus 2 terjadi peningkatan yang signifikan sebanyak $83,33 \%$ siswa yang sudah tuntas. Siswa yang belum tuntas pun menurun awalnya di pra siklus ada $61,11 \%$ turun menjadi $44,44 \%$ di siklus 1 dan sebanyak 16,67\% pada siklus 2 turun lagi. Hal ini menunjukkan bahwa penggunaan model pembelajaran Cooperative Learning pada siklus 1 dan siklus 2 dapat meningkatkan hasil belajar siswa pada mata pelajaran Tema 4 Sub Tema 3 Cara Memelihara Organ Peredaran Darah Manusia.

\section{SIMPULAN}

Penelitian tindakan kelas yang dilaksanakan dengan mengimplementasikan model pembelajaran Cooperative Learning bertujuan untuk meningkatkan hasil belajar siswa pada mata pelajaran Tema 4 Sub Tema 3 Cara Memelihara Organ Peredaran Darah Manusia materi Pantun, Gotong Royong dan Interaksi Sosial. Dari hasil penelitian menunjukkan adanya peningkatan aktivitas belajar siswa pada setiap indikatornya. Hal ini membuktikan bahwa model pembelajaran Cooperative Learning mampu meningkatkan aktivitas belajar siswa. Peningkatan aktivitas belajar siswa juga didukung dengan meningkatnya hasil belajar siswa. 
Implikasi dari penelitian ini yaitu, guru diharapkan untuk menerapkan model pembelajaran Cooperative Learning karena model pembelajaran ini terbukti mampu meningkatkan hasil belajar siswa pada mata pelajaran Tema 4 Sub Tema 3 Cara Memelihara Organ Peredaran Darah Manusia materi Pantun, Gotong Royong dan Interaksi Sosial. Berdasarkan data yang diperoleh hasil belajar siswa mengalami peningkatan. Selain guru menerapkan model pembelajaran ini, guru juga mampu menguasai strategi mengajar yang baik untuk mencapai hasil belajar yang baik pula.

\section{DAFTAR PUSTAKA}

Ali, M. 1987. Penelitian Kependidikan Prosedur Dan Srategi. Bandung: Angkasa.

Anita, Lie. 2004. Cooperative Learning: Mempraktekkan Cooperative Learning di Ruang-Ruang Kelas. Jakarta: PT. Grasindo.

BSNP. 2007. Pedoman Peilaian Hasil Belajar di Sekolah Dasar. Jakarta: DEPDIKNAS.

Isjoni. 2010. Cooperative Learning Efektivitas Pembelajaran Kelompok. Bandung: Alfabeta.

Pelajaran.co.id, "Langkah - langkah Penelitian Tindakan Kelas "<https://www.pelajaran.co.id/2019/15/pengertian-ptk-tujuan-karakteristikprinsip-langkah-dan-model-penelitian-tindakan-kelasptk.html\#: :text=Langkah\%2DLangkah\%20Penelitian\%20Tindakan\%20Kelas,ti ndakan\%20(Observation\%20and\%20evaluation)> [di akses pada tanggal 20 Oktober 2020]

Suharsimi Arikunto,Suhardjono \& Supardi. (2010). Penelitian Tindakan Kelas. Jakarta: Bumi Aksara.

Suwardi. (2018). Penerapan Model Pembelajaran Kooperatif untuk Meningkatkan Hasil Belajar dan Aktivitas Siswa Sekolah Dasar. Proceeding Biology Education Conference Volume 15, Nomor 1 Halaman 53 - 56.

Wawasanpengajaran.blogspot.com, "Kelebihan dan Kekurangan Metode Cooperative Learning " $<$ https://wawasanpengajaran.blogspot.com/2017/08/kelebihan-dankekurangan-metode.html> [di akses pada tanggal 20 Oktober 2020] 